\title{
Application of Post-Emergence ALS Inhibitor HeRbicides ASSOCIATED OR NOT TO GLYPHOSATE IN RR/STS SOYBEAN ${ }^{1}$
}

\author{
Aplicação em Pós-Emergência de Herbicidas Inibidores da ALS Associados ou Não ao \\ Glyphosate em Soja RR/STS
}

\author{
SILVA, A.F.M. ${ }^{2}$, ALBRECHT, A.J.P. ${ }^{3}$, ALBRECHT, L.P. ${ }^{3}$, VICTORIA FILHO, R. ${ }^{2}$ and \\ GIOVANELLI, B.F. ${ }^{2}$
}

\begin{abstract}
The aim of this study was to evaluate the selectivity of ALS inhibitor herbicides, applied isolated and associated with glyphosate in post-emergence of soybean cultivar presenting the RR/STS technologies. The experimental design was a randomized block with four replications and ten treatments. The treatments consisted of the application of glyphosate and ALS inhibitors herbicides, isolated and associated with glyphosate. The application of treatments occurred in V4 stage of plant development. The evaluation of phytointoxication, SPAD index was conducted, as well as variables related to agronomic performance (height, number of pods per plant, yield and mass of a thousand seeds). Yet additional test with the same cultivar and treatment was conducted in a greenhouse in a completely randomized design with four replications. Soybean cultivar CD 2630 RR/STS presented itself tolerant to application in post-emergence herbicides used alone or combined with glyphosate. Except to metsulfuron-methyl $\left(2.4 \mathrm{~g}\right.$ a.i. ha $\left.{ }^{-1}\right)$, associated or not with glyphosate (960 g a.e. ha ${ }^{-1}$ ).
\end{abstract}

Keywords: sulfonylurea tolerant soybeans, phytointoxication, chemical management, Glycine max.

RESUMO - O objetivo do presente trabalho foi avaliar a seletividade de herbicidas inibidores da ALS, aplicados isoladamente e associados com glyphosate, em pós-emergência de cultivar de soja contendo as tecnologias RR/STS. O delineamento experimental foi de blocos casualizados, com quatro repetições e dez tratamentos. Os tratamentos foram constituídos da aplicação de glyphosate e herbicidas inibidores da ALS, isolados e associados com glyphosate. A aplicação dos tratamentos ocorreu no estádio de desenvolvimento V4 das plantas. Foi realizada avaliação de fitointoxicação, indice SPAD, bem como de variáveis relacionadas ao desempenho agronômico (altura, número de vagens por planta, produtividade e massa de mil sementes). Ainda, foi conduzido ensaio complementar, com o mesmo cultivar e tratamentos em casa de vegetação, em delineamento inteiramente casualizado, com quatro repetições. O cultivar de soja CD 2630 RR/STS apresentou-se tolerante à aplicação em pós-emergência dos herbicidas utilizados, associados ou não com glyphosate, exceção feita ao metsulfuron-methyl (2,4 g i.a. ha $\left.{ }^{-1}\right)$, associado ou não com glyphosate (960 g e.a. ha-1).

Palavras-chave: soja tolerante as sulfoniluréias, fitointoxicação, manejo químico, Glycine max.

\section{INTRODUCTION}

The growth of areas occupied by soybean crops in Brazil, in 2014/2015, reached 32.09 million hectares (Conab, 2015), with prevision to expand to 32.20 million hectares in 2015/ 2016 (Céleres, 2015a). Another important factor is that crops of soybean RR (Roundup Ready) correspond to $93.5 \%$ of total soybean cultivated area in Brazil in 2014/2015 (Céleres, 2015b).

Recebido para publicação em 12.2.2016 e aprovado em 6.4.2016.

2 Universidade de São Paulo/Escola Superior de Agrícola “Luiz de Queiroz”, Piracicaba-SP, Brasil, <afmoreirasilva@usp.br>; ${ }^{3}$ Universidade Federal do Paraná, Palotina-PR, Brasil. 
With the arrival of soybean RR, glyphosate started to be the most used herbicide, however, ALS inhibitor herbicides, such as those belonging to the chemical group of sulfonylureas, among other, are important and must be considered in management, especially for the prevention of resistant weeds. Shaner (2000) already warned that, although glyphosate tolerant crops were a huge tool in weed management, the intensive use of this herbicide in RR crops could entail problems, especially in the selection of resistant biotypes.

Soybean tolerant to sulfonylureas (STS) was developed through seed mutagenesis technique, using the alkylating agent ethyl methanesulfonate (EMS), not regarding transgenic crops. The EMS agent do not cause mutation by insertion in DNA, but by modification of an existing base, introducing an alkyl radical - in this case, ethil - frequently in the nitrogenous base guanine (Rogozin et al., 2001; Greene et al., 2001).

Mutant seeds from the soybean cultivar Williams 82 were selected according to the tolerant to sulphonylorea chlorsulfuron. After improving process, the soybean cultivar W20 was obtained, presenting high levels of tolerance, post and pre-emergence, for some sulfonylureas. Studies show that this characteristic is determined by a semidominant allele, called Als1. Studies such as these are fundamentally important to identify other mutations and, consequently, increase these soybean cultivars' tolerance to sulfonylureas and other ALS inhibiting families (Sebastian et al., 1989; Ghio et al., 2013; Walter et al., 2014).

Soybean tolerance to some sulfonylureas was obtained via conventional techniques of genetic improvement; thus, STS cultivars contain a gene that increases the degradation of some herbicides in the plant, such as chlorimuron-ethyl, which, when applied in doses up to four times higher than the recommended dose for non-tolerant cultivars, shows none significant damages (Roso and Vidal, 2011).

Nowadays, in Argentina, more than 26 STS soybean cultivars from many maturation groups are available for farmers. In this country, STS technology has been used as a tool for grasses in general, voluntary plants of RR corn and, yet, Conyza spp., together with the application of a herbicide, with two sulfonylureas in its formula: sulfometuronmethyl (111.11 $\mathrm{g} \mathrm{kg}^{-1}$ ) and chlorimuron-ethyl $\left(148.15 \mathrm{~g} \mathrm{~kg}^{-1}\right)$, with recommended doses of 90 to 100 g p.c. ha-1 in association to glyphosate (DuPont, 2012; Infocampo, 2015).

The rotation of herbicides action mechanisms has fundamental role in the prevention of resistant biotypes. In this context, new technologies and cultivars tolerant to herbicides, such as soybean imidazolinone tolerant, 2.4-D, sulfonylureas, among other molecules, deserve highlights (Riar et al., 2013).

Herbicide association is an important tool for the management of plants which are difficult to control, and many studies report its applications, advantages and disadvantages. According to Gazziero (2015), who has interviewed rural producers and professionals of the area, $97 \%$ of the interviewees state that mix in tanks is a normal practice. It is, then, necessary to discuss this theme with the competent bodies.

The association between chlorimuronethyl with other molecules, highlighting glyphosate, was recently studied by many authors, among who are Albrecht et al. (2012), Oliveira Neto et al. (2013), Chahal et al. (2014) and Belfry et al. (2015). These studies were directed especially for difficult to control weed management, and also to the selectivity of this association for soybean crops.

Due to the lack of information regarding STS technology, added RR technology, it is important to characterize the selectivity of ALS inhibitor herbicides, isolated or associated to glyphosate, in post-emergence for RR/STS soybean crops, since there are few reports in literature about this technology, which has great use potential by farmers in weed control.

The objective of the present study was to evaluate ALS inhibitor herbicide's selectivity applied in post-emergence in soybean cultivar CD 2630 RR/STS. 


\section{MATERIAL AND METHODS}

The present study consisted in two experiments conducted in the 2014/2015 crop, in the city of Piracicaba, mid-eastern region of São Paulo state. Experiment 1 was conducted in the field and experiment 2 , in a greenhouse.

Table 1 presents the chemical and physical analysis from the soil in the experimental area and also for the soil used in the greenhouse vases.
In Figure 1, the distribution of precipitation and temperature during the period when the experiment was conducted in the field is displayed.

For experiment 1, the experimental units consisted in portions of five meters of length and six soybean lines. For experiment 2 , the experimental units consisted by seven liter vases filled with soil of medium texture. Six seeds were sowed per vase and, after emergence, the seedlings were thinned, leaving only three plants per vase.

Table 1 - Result from soil's chemical analysis from the experimental area, in the depth of 0 to $20 \mathrm{~cm}$. Piracicaba - SP, harvest 2014/2015

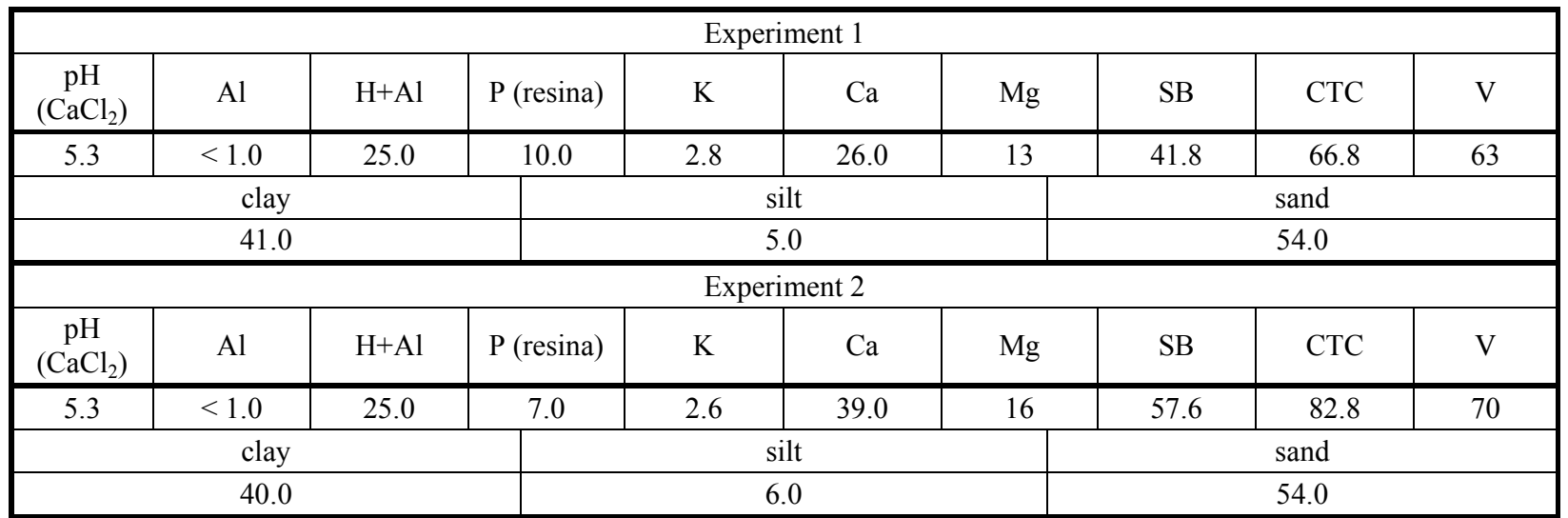

Units: $\mathrm{Al}, \mathrm{H}+\mathrm{Al}, \mathrm{K}, \mathrm{Ca}, \mathrm{Mg}, \mathrm{SB}$ and $\mathrm{CTC}\left(\mathrm{mmol}_{\mathrm{c}} \mathrm{dm}^{-3}\right) ; \mathrm{P}(\mathrm{resin})\left(\mathrm{mg} \mathrm{dm} \mathrm{d}^{-3}\right)$; V, clay, silt and sand (\%).

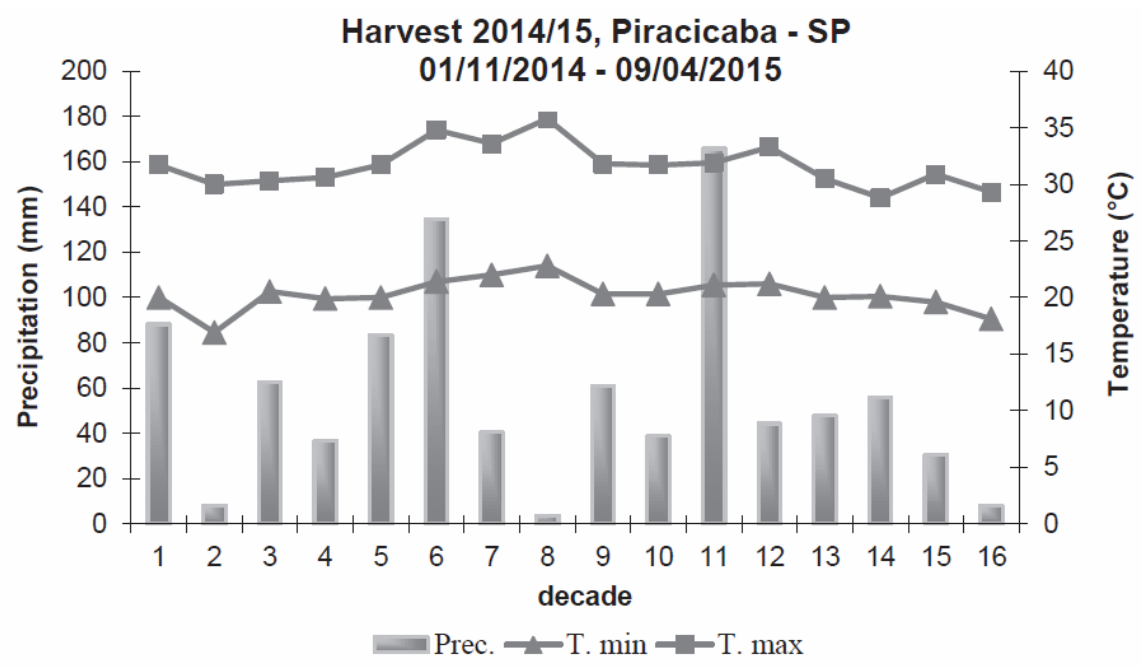

Source: LEB - ESALQ/USP

Figure 1 - Representation of precipitation, average minimum and average maximum temperatures for the period relative to soybean crop cycle, in Piracicaba city, harvest 2014/2015. 
Soybean cultivar CD 2630 RR/STS was used. It presents indeterminate growing habit, relative maturity group (RMG) 6.3, resistance to frogeye leaf spot, oidium, stem canker and cist nematodes, types 3 and 14 . It is adapted to the South region of Brazil, Paraguay and regions of Mato Grosso do Sul and São Paulo, with recommended sowing from 20 of September to 10 of December and population of 240 to 300 thousand plants ha-1 (Coodetec, 2012).

The used experimental design was randomized blocks for experiment 1 and completely randomized for experiment 2 , with four repetitions and ten treatments (Table 2).

The employment of fertilizing practices, crop installation and plant health management were performed according to Embrapa (2013) recommendations, and all portions were kept free from weed interference, through manual weeding.

In both experiments, the use of treatment was during soybean V4 development level. For experiment 1 , the treatment was applied by backpack sprayer propelled by $\mathrm{CO}_{2}$, equipped with a four pulverization point bar, in constant pressure of 2 Bar, providing a volume of $200 \mathrm{~L} \mathrm{ha}^{-1}$, and velocity of $1 \mathrm{~m} \mathrm{~s}^{-1}$, with the tips positioned to a height of $50 \mathrm{~cm}$ from the target. In experiment 2 , the application was via automated pulverization chamber, with a flat fan nozzle, even jet, model XR 80.02, calibrated for a volume of $200 \mathrm{~L} \mathrm{ha}^{-1}$.

For experiment 1 , the experimental units consisted of five meters long portions and six lines of soybean, being considered as usable area the four central lines, discarding the first and last meter of the portion. In experiment 2 , the experimental units consisted of 7 liter vases filled with soils of medium texture. Six seeds were sowed per vase and, after emergence, the seedlings were thinned, leaving only three plants per vase.

The photo intoxication was evaluated through visual perception, in which percentage grades were attributed varying from 0 to $100 \%$ in each experimental unit (where 0 represents absence of injuries and 100\%, plant death), considering, in this case, significant visible symptoms in plants, according to its development (SBCPD, 1995). This evaluation was performed in experiment 1 on $7,14,21$ and 28 days after application (DAA) and, in experiment 2, on 7, 14 and 21 DAA.

The evaluation of the SPAD index was also performed in the soybean crop, in which the portable SPAD-502 meter from Minolta was used. This instrument evaluated quantitatively the intensity of the color green on leafs, through light transmissions at 650 $\mathrm{nm}$, where light is absorbed by the chlorophyll molecule, and at $940 \mathrm{~nm}$, where there is not any absorption. With these two values, the equipment calculates a number, or SPAD index, which, normally, is highly correlated with chlorophyll levels on the leaf (Markwell et al., 1995). For experiment 1 , the evaluation occurred on 21 and 28 DAA and 10 plants were submitted to the test, chosen randomly in the portion's usable area; and for experiment 2, on 7,14 and 21 DAA, evaluating three plants from each vase.

An evaluation of related variables regarding agronomic performance (plant height, number of pod per plant, productivity and mass of a thousand seeds) was carried for experiment 1 .

The height evaluation (experiment 1) was performed when plants have achieved R7 stadium. To determine the variable, ten plants were evaluated, chosen randomly in the usable area of the portions, with measurements done with the aid of a millimeter wood ruler, with the results in centimeters. The number of pods per plant was assessed in full ripening (R8 stadium), by manually counting the number of present pods, also in ten plants chosen randomly in the usable area of each portion.

Three plants from the central lines were harvested, ignoring the first and the last portion meter, totalizing a harvest area of $4.05 \mathrm{~m}^{2}$. Plants were on $\mathrm{R} 8$, which means that 95\% of the pods showed typical ripe pod coloration (Fehr et al., 1971). Afterwards, the pods were threshed in a thresher for experiments, cleaned with the aid of sieves and stored in paper bags for later analysis and evaluations. The grains produced in each portion had their mass assessed and humidity corrected for $13 \%$; from these data, productivity was calculated. For the mass of a thousand 
Table 2 - Trataments composed by application with or without association of ALS inhibitors with glyphosate. Piracicaba - SP, harvest 2014/2015

\begin{tabular}{|l|l|c|}
\hline \multicolumn{1}{|c|}{ Tratament } & \multicolumn{1}{|c|}{ Commercial product } & \multicolumn{1}{c|}{$\begin{array}{c}\text { Doses } \\
\left(\mathrm{g} \text { a.i. } \text { ha }^{-1}\right)^{*}\end{array}$} \\
\hline 1. Control group & \multicolumn{1}{c|}{-} & - \\
\hline 2. Glyphosate & Roundup Ready & 960 \\
\hline 3. Metsulfuron-methyl & Ally & 2.4 \\
\hline 4. Chlorimuron-ethyl & Classic & 20 \\
\hline 5. Nicosulfuron & Sanson & 60 \\
\hline 6. Cloransulam-methyl & Pacto & 40 \\
\hline 7. Glyphosate + metsulfuron-methyl & Roundup Ready + Ally & $960+2.4$ \\
\hline 8. Glyphosate + chlorimuron-ethyl & Roundup Ready + Classic & $960+20$ \\
\hline 9. Glyphosate + nicosulfuron & Roundup Ready + Sanson & $960+60$ \\
\hline 10. Glyphosate + cloransulam-methyl & Roundup Ready + Pacto & $960+40$ \\
\hline
\end{tabular}

* Grams of active ingredient by hectare. Doses in grams of equivalent acid per hectare (g e.a. ha ${ }^{1}$ ), for glyphosate herbicide.

seeds, the mass of two sub-samples of 100 seeds per portion were checked; the values were then multiplied by ten, and the humidity was corrected to $13 \%$.

For experiment 2, height evaluation was held on 7,14 and $21 \mathrm{DAA}$, through checking three plants from each vase. When the majority of plants had reached R2 development stage, aerial and root systems were collected from each one of them, in order to measure mass of fresh and dry aerial part and dry mass from the root system. For drying, an oven with forced ventilation was used for $72 \mathrm{~h}$, at $65^{\circ} \mathrm{C}$ and, for mass, an analytical scale with three decimal places of precision.

The obtained data was submitted to variance analysis and to the $\mathrm{F}$ test, and the averages of the treatments, compared by the Tukey test $(\mathrm{p}<0.05)$, according to PimentelGomes and Garcia (2002).

\section{RESULTS AND DISCUSSION}

The following results are regarding experiment 1 (Tables 3, 4 and 5).

According to Table 3, on 7, 14 and 21 DAA the applications of metsulfuron-methyl $\left(2.4 \mathrm{~g}\right.$ a.i. $\left.\mathrm{ha}^{-1}\right)$ and glyphosate + metsulfuronmethyl (960 g a.e. ha- $+2.4 \mathrm{~g}^{-1}$ a.i. ha $\left.{ }^{-1}\right)$ in post-emergence have caused damages on soybean plants, more severely on 28 DAA, with phytointoxication percentages of 32.5 and 87.5 , respectively. The other treatments did not present phytointoxication in the last evaluation. The applications of nicosulfuron $\left(60 \mathrm{~g}\right.$ a.i. ha $\left.{ }^{-1}\right)$ and glyphosate + nicosulfuron (960 g a.e. ha-1 +60 g a.i. ha ${ }^{-1}$ ) post-emergence have also caused significant symptoms of phytointoxication, however only on 7 DAA.

According to Marchi et al. (2013), the glyphosate + chlorimuron-ethyl applications, until a dose of 960 g a.e. ha ${ }^{-1}+10,0$ g a.i. ha ${ }^{-1}$; and glyphosate + cloransulam-methyl, until a dose of 960 g a.e. ha-1 $+40,0 \mathrm{~g}$ a.i. ha-1, did not cause visible symptoms of phytointoxication in soybean cultivar P98Y70, on 31 DAA.

The application of chlorimuron-ethyl (18 g a.i. ha ${ }^{-1}$ ), in pre-emergence, did not cause significant symptoms of phytointoxication in the evaluations held two and four weeks after soybean emergence in cultivars S03W4, Madison, OAC Lakeview and S23T5. The same was observed for cloransulam-methyl application in a dose of $70 \mathrm{~g}$ a.i. ha ${ }^{-1}$ (Belfry et al., 2015). The application of imazethapyr, molecule that belongs to the ALS inhibitor group, has also caused injuries in soybean (Walsh et al., 2015).

Results compatible with phytointoxication evaluation were observed for the SPAD index evaluation (Table 4). The application of glyphosate + metsulfuron-methyl $\left(960\right.$ g a.e. ha ${ }^{-1}+2.4$ g a.i. ha $\left.{ }^{-1}\right)$ in postemergence has presented values of SPAD index inferior than those from other treatments, in both evaluations. 
Table 3 - Evaluation of phytointoxication (\%) on 7, 14 and 21 DAA from soybean plants RR/STS under the application with or without association of ALS inhibitors with glyphosate (experiment 1). Piracicaba - SP, harvest 2014/2015

\begin{tabular}{|c|c|c|c|c|c|}
\hline \multirow{3}{*}{ Tratament } & \multirow{3}{*}{$\begin{array}{c}\text { Doses } \\
\left(\mathrm{g} \mathrm{a.i.} \mathrm{ha}^{-1}\right)^{1 /}\end{array}$} & \multicolumn{4}{|c|}{ Phytointoxication } \\
\hline & & $7 *$ & $14^{*}$ & $21 *$ & $28 *$ \\
\hline & & \multicolumn{4}{|c|}{ (DAA) } \\
\hline 1. Control group & - & $0.0 \mathrm{a}$ & $0.0 \mathrm{a}$ & $0.0 \mathrm{a}$ & $0.0 \mathrm{a}$ \\
\hline 2. Glyphosate & 960 & $0.0 \mathrm{a}$ & $0.0 \mathrm{a}$ & $0.0 \mathrm{a}$ & $0.0 \mathrm{a}$ \\
\hline 3. Metsulfuron-methyl & 2.4 & $5.0 \mathrm{c}$ & $20.0 \mathrm{~b}$ & $23.8 \mathrm{~b}$ & $32.5 \mathrm{~b}$ \\
\hline 4. Chlorimuron-ethyl & 20 & $0.8 \mathrm{ab}$ & $0.0 \mathrm{a}$ & $0.0 \mathrm{a}$ & $0.0 \mathrm{a}$ \\
\hline 5. Nicosulfuron & 60 & $3.5 \mathrm{c}$ & $5.5 \mathrm{a}$ & $0.0 \mathrm{a}$ & $0.0 \mathrm{a}$ \\
\hline 6. Cloransulam-methyl & 40 & $0.0 \mathrm{a}$ & $0.0 \mathrm{a}$ & $0.0 \mathrm{a}$ & $0.0 \mathrm{a}$ \\
\hline 7. Glyphosate + metsulfuron-methyl & $960+2.4$ & $30.0 \mathrm{~d}$ & $70.0 \mathrm{c}$ & $76.3 \mathrm{c}$ & $87.5 \mathrm{c}$ \\
\hline 8. Glyphosate + chlorimuron-ethyl & $960+20$ & $0.0 \mathrm{a}$ & $0.0 \mathrm{a}$ & $0.0 \mathrm{a}$ & $0.0 \mathrm{a}$ \\
\hline 9. Glyphosate + nicosulfuron & $960+60$ & $3.3 \mathrm{bc}$ & $3.8 \mathrm{a}$ & $3.3 \mathrm{a}$ & $0.0 \mathrm{a}$ \\
\hline 10. Glyphosate + cloransulam-methyl & $960+40$ & $0.8 \mathrm{ab}$ & $0.8 \mathrm{a}$ & $0.8 \mathrm{a}$ & $0.0 \mathrm{a}$ \\
\hline Average & & 4.33 & 10.00 & 10.40 & 12.00 \\
\hline VC (\%) & & 23.95 & 36.72 & 24.38 & 14.79 \\
\hline
\end{tabular}

${ }^{1 /}$ Grams of active ingredient per hectare. Doses in grams of equivalent acid per hectare (g e.a. ha ${ }^{-1}$ ), glyphosate herbicide. ${ }^{*}$ Averages followed by the same letter in column do not differ statistically between each other at $5 \%$ probability by Tukey test.

Table 4 - Evaluation of the SPAD index in soybean plants RR/STS under application with or qithout ALS inhibitors with glyphosate (experiment 1). Piracicaba - SP, harvest 2014/2015

\begin{tabular}{|c|c|c|c|}
\hline \multirow{3}{*}{ Tratament } & \multirow{3}{*}{$\begin{array}{c}\text { Doses } \\
\left(\mathrm{g} \mathrm{a.i.} \mathrm{ha}^{-1}\right)^{-1}\end{array}$} & \multicolumn{2}{|c|}{ SPAD } \\
\hline & & $21 *$ & $28 *$ \\
\hline & & \multicolumn{2}{|c|}{ (DAA) } \\
\hline 1. Control group & - & $42.7 \mathrm{a}$ & $42.3 \mathrm{a}$ \\
\hline 2. Glyphosate & 960 & $41.5 \mathrm{a}$ & $42.3 \mathrm{a}$ \\
\hline 3. Metsulfuron-methyl & 2.4 & $42.5 \mathrm{a}$ & $39.5 \mathrm{a}$ \\
\hline 4. Chlorimuron-ethyl & 20 & $41.5 \mathrm{a}$ & $41.0 \mathrm{a}$ \\
\hline 5. Nicosulfuron & 60 & $42.2 \mathrm{a}$ & $39.8 \mathrm{a}$ \\
\hline 6. Cloransulam-methyl & 40 & $42.5 \mathrm{a}$ & $41.3 \mathrm{a}$ \\
\hline 7. Glyphosate + metsulfuron-methyl & $960+2.4$ & $35.8 \mathrm{~b}$ & $33.5 \mathrm{~b}$ \\
\hline 8. Glyphosate + chlorimuron-ethyl & $960+20$ & $41.5 \mathrm{a}$ & $42.2 \mathrm{a}$ \\
\hline 9. Glyphosate + nicosulfuron & $960+60$ & $41.8 \mathrm{a}$ & $41.0 \mathrm{a}$ \\
\hline 10. Glyphosate + cloransulam-methyl & $960+40$ & $41.6 \mathrm{a}$ & $40.4 \mathrm{a}$ \\
\hline Average & & 41.34 & 40.34 \\
\hline $\mathrm{VC}(\%)$ & & 3.72 & 4.56 \\
\hline
\end{tabular}

${ }^{1 /}$ Grams of active ingredient per hectare. Doses in grams of equivalent acid per hectare (g e.a. ha $\left.{ }^{-1}\right)$, glyphosate herbicide. * Averages followed by the same letter in column do not differ statistically between each other at $5 \%$ probability by Tukey test.

The application of metsulfuron-methyl $\left(2.4 \mathrm{~g}\right.$ a.i. $\left.\mathrm{ha}^{-1}\right)$ in post-emergence, with or without association to glyphosate (960 g a.e. ha-1), has reduced the number of pod per plant to zero. Plant height was also negatively influenced. However, the other treatments did not reduce the number of pods per plant (Table 5). These results contrast with those of Viana et al. (2014), in which: soybean cultivar CD 250 RR/STS was tolerant to the application of metsulfuron-methyl in doses of $1.8 ; 3.6 ; 5.4$; and 7.2 (g a.i. ha ${ }^{-1}$ ).

The productivity variable was negatively influenced by the application of metsulfuronmethyl $\left(2.4 \mathrm{~g}\right.$ a.i. $\left.\mathrm{ha}^{-1}\right)$ in post-emergence, 
Table 5 - Number of pods, productivity $\left(\mathrm{kg} \mathrm{ha}^{-1}\right)$ and height $(\mathrm{cm})$ of soybean plants RR/STS under application with or without ALS inhibitors with glyphosate (experiment 1). Piracicaba - SP, harvest 2014/2015

\begin{tabular}{|l|c|c|c|c|}
\hline \multicolumn{1}{|c|}{ Tratament } & $\begin{array}{c}\text { Doses } \\
\left(\mathrm{g} \text { a.i. ha }{ }^{-1}\right)^{1 /}\end{array}$ & $\begin{array}{c}\text { Number of } \\
\text { pods* }\end{array}$ & Productivity* & Height* \\
\hline 1. Control group & - & $38.9 \mathrm{a}$ & $3388.6 \mathrm{a}$ & $101.2 \mathrm{a}$ \\
\hline 2. Glyphosate & 960 & $36.1 \mathrm{a}$ & $3283.6 \mathrm{a}$ & $99.3 \mathrm{a}$ \\
\hline 3. Metsulfuron-methyl & 2.4 & $0.0 \mathrm{~b}$ & $0.0 \mathrm{~b}$ & $74.6 \mathrm{~b}$ \\
\hline 4. Chlorimuron-ethyl & 20 & $37.2 \mathrm{a}$ & $3238.2 \mathrm{a}$ & $99.2 \mathrm{a}$ \\
\hline 5. Nicosulfuron & 60 & $38.3 \mathrm{a}$ & $3079.0 \mathrm{a}$ & $101.4 \mathrm{a}$ \\
\hline 6. Cloransulam-methyl & 40 & $38.6 \mathrm{a}$ & $3091.5 \mathrm{a}$ & $99.5 \mathrm{a}$ \\
\hline 7. Glyphosate + metsulfuron-methyl & $960+2.4$ & $0.0 \mathrm{~b}$ & $0.0 \mathrm{~b}$ & $0.0 \mathrm{c}$ \\
\hline 8. Glyphosate + chlorimuron-ethyl & $960+20$ & $39.8 \mathrm{a}$ & $3045.2 \mathrm{a}$ & $100.9 \mathrm{a}$ \\
\hline 9. Glyphosate + nicosulfuron & $960+60$ & $38.0 \mathrm{a}$ & $3286.1 \mathrm{a}$ & $101.4 \mathrm{a}$ \\
\hline 10. Glyphosate + cloransulam-methyl & $960+40$ & $38.2 \mathrm{a}$ & $3121.4 \mathrm{a}$ & $101.4 \mathrm{a}$ \\
\hline Average & & 30.52 & 2554.37 & 87.86 \\
\hline VC $(\%)$ & & 8.91 & 7.31 & 2.55 \\
\hline
\end{tabular}

${ }^{1 /}$ Grams of active ingredient per hectare. Doses in grams of equivalent acid per hectare (g e.a. ha ${ }^{-1}$ ), glyphosate herbicide. * Averages followed by the same letter in column do not differ statistically between each other at $5 \%$ probability by Tukey test.

with or without association to glyphosate (960 g a.e. ha $\left.{ }^{-1}\right)$, while the application of other treatments have not influenced it.

According to Procópio et al. (2006), the application of glyphosate + chlorimuron-ethyl (1.620 g a.e. ha ${ }^{-1}+20$ g a.i. ha $\left.{ }^{-1}\right)$, in pre-sowing did not reduce productivity in soybean RR. The same was observed by Maciel et al. (2009) for application in post-emergence of glyphosate + chlorimuron-ethyl (960 g a.e. ha ${ }^{-1}+$ $10 \mathrm{~g}$ a.i. ha-1). Giovanelli et al. (2014) have verified the same for the appplication, in post-emergence, of nicosulfuron, until the dose of $200 \mathrm{~g}$ a.i. ha ${ }^{-1}$, for the cultivar CD 250 RR/STS.

Results similar to the ones obtained in experiment 1 were observed in experiment 2 (conducted in the greenhouse) (Tables 6 to 9).

Regarding the evaluation of phytointoxication (Table 6), it is observed that the application in post-emergence of glyphosate + metsulfuron-methyl (960 g a.e. ha ${ }^{-1}+$ $2.4 \mathrm{~g}^{2}$.i. $\mathrm{ha}^{-1}$ ) has presented higher percentages than the other treatments, in the order of 23.8, 48.8 and 61.3 , for evaluations held on 7,14 and 21 DAA, respectively. On 21 DAA, it is possible to observe that only on applications of metsulfuron-methyl ( $2.4 \mathrm{~g}$ a.i. ha $\mathrm{h}^{-1}$ ) in post-emergence, with or without glyphosate (960 g a.e. ha $\left.{ }^{-1}\right)$, was statistically different than the control group (Table 6).

The other treatments have not caused significant phytointoxication symptoms in soybean plants on 14 and 21 DAA. On 7 DAA, phytointoxication of $5 \%$ was observed for application in post-emergence of nicosulfuron (60 g a.i. ha $\mathrm{g}^{-1}$ ), differing from the control group. However, in the following evaluations significant symptoms were not identified. The results found by Giovanelli et al. (2014) for application of nicosulfuron in post-emergence show that until doses of $200 \mathrm{~g}$ i.a. ha- ${ }^{-1}$ no negative effect occurred in the development of the cultivar CD 250 RR/STS.

Also, on 7 DAA, phytointoxication of $2.3 \%$ for application of chlorimuron-ethyl (20 g a.i. ha ${ }^{-1}$ ), post-emergence, was verified, differing from the control group. Nonetheless, in the following evaluations no significant symptoms were found. According to Reddy e Whiting (2000), soybean cultivar DP $3571 \mathrm{~S}$ (tolerant to sulfonylureas) did not have development negatively influenced by the application of chlorimuron-ethyl (22 g a.i. ha-1), in sequential application in early and late post-emergence.

According to Table 7 , the application in post-emergence of glyphosate + metsulfuronmethyl (960 g a.e. ha ${ }^{-1}+2.4$ g a.i. ha ${ }^{-1}$ ) has 
Table 6 - Evaluation of phytointoxication (\%) on 7, 14 and 21 DAA from soybean plants RR/STS under the application with or without association of ALS inhibitors with glyphosate (experiment 2). Piracicaba - SP, harvest 2014/2015

\begin{tabular}{|c|c|c|c|c|}
\hline \multirow{3}{*}{ Tratament } & \multirow{3}{*}{$\begin{array}{c}\text { Doses } \\
\left(\mathrm{g} \mathrm{a.i.} \mathrm{ha}^{-1}\right)^{1 /}\end{array}$} & \multicolumn{3}{|c|}{ Phytointoxication } \\
\hline & & $7 *$ & $14 *$ & $21 *$ \\
\hline & & \multicolumn{3}{|c|}{ DAA } \\
\hline 1. Control group & - & $0.0 \mathrm{a}$ & $0.0 \mathrm{a}$ & $0.0 \mathrm{a}$ \\
\hline 2. Glyphosate & 960 & $0.0 \mathrm{a}$ & $0.0 \mathrm{a}$ & $0.0 \mathrm{a}$ \\
\hline 3. Metsulfuron-methyl & 2.4 & $10.0 \mathrm{~d}$ & $28.8 \mathrm{~b}$ & $30.0 \mathrm{~b}$ \\
\hline 4. Chlorimuron-ethyl & 20 & $2.3 \mathrm{~b}$ & $1.5 \mathrm{a}$ & $0.8 \mathrm{a}$ \\
\hline 5. Nicosulfuron & 60 & $5.5 \mathrm{c}$ & $3.8 \mathrm{a}$ & $3.8 \mathrm{a}$ \\
\hline 6. Cloransulam-methyl & 40 & $0.0 \mathrm{a}$ & $0.0 \mathrm{a}$ & $0.0 \mathrm{a}$ \\
\hline 7. Glyphosate + metsulfuron-methyl & $960+2.4$ & $23.8 \mathrm{e}$ & $48.8 \mathrm{c}$ & $61.3 \mathrm{c}$ \\
\hline 8. Glyphosate + chlorimuron-ethyl & $960+20$ & $0.0 \mathrm{a}$ & $0.0 \mathrm{a}$ & $0.0 \mathrm{a}$ \\
\hline 9. Glyphosate + nicosulfuron & $960+60$ & $3.5 \mathrm{bc}$ & $5.0 \mathrm{a}$ & $3.3 \mathrm{a}$ \\
\hline 10. Glyphosate + cloransulam-methyl & $960+40$ & $2.8 \mathrm{bc}$ & $2.0 \mathrm{a}$ & $0.8 \mathrm{a}$ \\
\hline Average & & 4.78 & 8.98 & 16.81 \\
\hline $\mathrm{VC}(\%)$ & & 14.22 & 19.02 & 16.81 \\
\hline
\end{tabular}

${ }^{1 /}$ Grams of active ingredient per hectare. Doses in grams of equivalent acid per hectare ( $\mathrm{g}$ e.a. ha ${ }^{-1}$ ), glyphosate herbicide. * Averages followed by the same letter in column do not differ statistically between each other at $5 \%$ probability by Tukey test.

Table 7 - Evaluation of the SPAD index in soybean plants RR/STS under application with or qithout ALS inhibitors with glyphosate (experiment 2). Piracicaba - SP, harvest 2014/2015

\begin{tabular}{|c|c|c|c|c|}
\hline \multirow{3}{*}{ Tratament } & \multirow{3}{*}{$\begin{array}{c}\text { Doses } \\
\left(\mathrm{g} \text { a.i. ha }{ }^{-1}\right)^{\frac{1}{}}\end{array}$} & \multicolumn{3}{|c|}{ SPAD } \\
\hline & & $7 *$ & $14 *$ & $21 *$ \\
\hline & & \multicolumn{3}{|c|}{ DAA } \\
\hline 1. Control group & - & $41.1 \mathrm{a}$ & $44.7 \mathrm{~A}$ & $44.3 \mathrm{a}$ \\
\hline 2. Glyphosate & 960 & $40.4 \mathrm{a}$ & $40.4 \mathrm{abc}$ & $41.9 \mathrm{a}$ \\
\hline 3. Metsulfuron-methyl & 2.4 & $31.5 \mathrm{bc}$ & $36.2 \mathrm{bc}$ & $33.6 \mathrm{~b}$ \\
\hline 4. Chlorimuron-ethyl & 20 & $41.5 \mathrm{a}$ & $41.4 \mathrm{ab}$ & $41.0 \mathrm{a}$ \\
\hline 5. Nicosulfuron & 60 & $39.4 \mathrm{a}$ & $38.9 \mathrm{bc}$ & $40.2 \mathrm{a}$ \\
\hline 6. Cloransulam-methyl & 40 & $39.4 \mathrm{a}$ & $41.0 \mathrm{abc}$ & $40.6 \mathrm{a}$ \\
\hline 7. Glyphosate + metsulfuron-methyl & $960+2.4$ & $29.4 \mathrm{c}$ & $28.1 \mathrm{~d}$ & $24.2 \mathrm{c}$ \\
\hline 8. Glyphosate + chlorimuron-ethyl & $960+20$ & $38.0 \mathrm{a}$ & $35.7 \mathrm{c}$ & $39.0 \mathrm{ab}$ \\
\hline 9. Glyphosate + nicosulfuron & $960+60$ & $36.5 \mathrm{ab}$ & $38.5 \mathrm{bc}$ & $39.9 \mathrm{ab}$ \\
\hline 10. Glyphosate + cloransulam-methyl & $960+40$ & $36.3 \mathrm{ab}$ & $38.3 \mathrm{bc}$ & $41.5 \mathrm{a}$ \\
\hline \multicolumn{2}{|l|}{ Average } & 37.33 & 38.29 & 38.60 \\
\hline \multicolumn{2}{|l|}{$\mathrm{VC}(\%)$} & 6.55 & 6.03 & 6.89 \\
\hline
\end{tabular}

${ }^{1 /}$ Grams of active ingredient per hectare. Doses in grams of equivalent acid per hectare (g e.a. ha $\left.{ }^{-1}\right)$, glyphosate herbicide. * Averages followed by the same letter in column do not differ statistically between each other at $5 \%$ probability by Tukey test.

shown lower values of SPAD index 21 DAA, when compared to other treatments, which are compatible with phytointoxication symptoms. Viana et al. (2014) have verified that soybean cultivar CD $250 \mathrm{RR} / \mathrm{STS}$ was tolerant to the application of metsulfuron-methyl in doses of 1.8; 3.6; 5.4; and 7.2 (g a.i. ha ${ }^{1}$ ).
Similar behavior of the other variables was observed for height (Table 8). The application of metsulfuron-methyl (2.4 g a.i. ha-1) in postemergence, with or without association with glyphosate (960 g a.e. ha ${ }^{-1}$ ), has significantly reduced soybean plants height, presenting the lowest numbers in all three evaluations. The 
other treatments did not reduce soybean plants height significantly.

The application of chlorimuron-ethyl (20 g a.i. ha $\mathrm{h}^{-1}$ ) and cloransulam-methyl (40 g a.i. ha-1) in post-emergence did not reduce fresh mass in soybean plants. However, the other treatments significantly reduced fresh mass when compared to the control group. The application of chlorimuron-ethyl (20 g a.i. ha $\left.{ }^{-1}\right)$ in post-emergence consisted in the only treatment that did not reduce dry mass significantly, when comparing to the control group. In contrast, the dry mass of the root system was reduced only by the application in post-emergence of metsulfuron-methyl (2.4 g a.i. ha $\left.\mathrm{g}^{-1}\right)$, with or without association to glyphosate (960 g a.e. ha ${ }^{-1}$ ) (Table 9).

Table 8 - Evaluation of height $(\mathrm{cm})$ on 7, 14 and 21 DAA of soybean plants RR/STS under application with or without association with ALS inhibitors with glyphosate (experiment 2). Piracicaba - SP, harvest 2014/2015

\begin{tabular}{|c|c|c|c|c|}
\hline \multirow{3}{*}{ Tratament } & \multirow{3}{*}{$\begin{array}{c}\text { Doses } \\
\left(\mathrm{g} \mathrm{a}^{\mathrm{i} .} \mathrm{ha}^{-1}\right)^{1 /}\end{array}$} & \multicolumn{3}{|c|}{ Height } \\
\hline & & $7 *$ & $14 *$ & $21 *$ \\
\hline & & \multicolumn{3}{|c|}{ DAA } \\
\hline 1. Control group & - & $42.8 \mathrm{ab}$ & $54.6 \mathrm{a}$ & $61.4 \mathrm{a}$ \\
\hline 2. Glyphosate & 960 & $44.7 \mathrm{a}$ & $54.1 \mathrm{a}$ & $59.7 \mathrm{a}$ \\
\hline 3. Metsulfuron-methyl & 2.4 & $36.2 \mathrm{bc}$ & $37.4 \mathrm{~b}$ & $39.0 \mathrm{~b}$ \\
\hline 4. Chlorimuron-ethyl & 20 & $47.9 \mathrm{a}$ & $57.1 \mathrm{a}$ & $61.4 \mathrm{a}$ \\
\hline 5. Nicosulfuron & 60 & $46.3 \mathrm{a}$ & $53.7 \mathrm{a}$ & $60.2 \mathrm{a}$ \\
\hline 6. Cloransulam-methyl & 40 & $44.8 \mathrm{a}$ & $52.8 \mathrm{a}$ & $59.9 \mathrm{a}$ \\
\hline 7. Glyphosate + metsulfuron-methyl & $960+2.4$ & $34.4 \mathrm{c}$ & $33.2 \mathrm{~b}$ & $31.4 \mathrm{~b}$ \\
\hline 8. Glyphosate + chlorimuron-ethyl & $960+20$ & $43.7 \mathrm{a}$ & $51.2 \mathrm{a}$ & $57.9 \mathrm{a}$ \\
\hline 9. Glyphosate + nicosulfuron & $960+60$ & $44.2 \mathrm{a}$ & $51.8 \mathrm{a}$ & $58.6 \mathrm{a}$ \\
\hline 10. Glyphosate + cloransulam-methyl & $960+40$ & $45.3 \mathrm{a}$ & $52.1 \mathrm{a}$ & $58.9 \mathrm{a}$ \\
\hline Average & & 43.01 & 49.78 & 54.80 \\
\hline VC (\%) & & 6.63 & 6.47 & 6.90 \\
\hline
\end{tabular}

1/Grams of active ingredient per hectare. Doses in grams of equivalent acid per hectare (g e.a. ha $\left.{ }^{-1}\right)$, glyphosate herbicide. ${ }^{*}$ Averages followed by the same letter in column do not differ statistically between each other at $5 \%$ probability by Tukey test.

Table 9 - Fresh and Dry mass of aerial part and dry mass of root system $(\mathrm{g})$ in soybean plants RR/STS under applicarion with or without ALS inhibitors associated with glyphosate (experiment 2). Piracicaba - SP, harvest 2014/2015

\begin{tabular}{|c|c|c|c|c|}
\hline Tratament & $\begin{array}{c}\text { Doses } \\
\left(\mathrm{g} \text { a.i. } \mathrm{ha}^{-1}\right)^{1 /}\end{array}$ & FMAP** & DMAP** & DMRS** \\
\hline 1. Control group & - & $143.2 \mathrm{a}$ & $28.7 \mathrm{a}$ & $15.9 \mathrm{a}$ \\
\hline 2. Glyphosate & 960 & $117.5 \mathrm{bc}$ & $24.0 \mathrm{bc}$ & $14.2 \mathrm{ab}$ \\
\hline 3. Metsulfuron-methyl & 2.4 & $38.4 \mathrm{~d}$ & $9.7 \mathrm{e}$ & $8.8 \mathrm{bc}$ \\
\hline 4. Chlorimuron-ethyl & 20 & $125.7 \mathrm{ab}$ & $25.9 \mathrm{ab}$ & $14.0 \mathrm{ab}$ \\
\hline 5. Nicosulfuron & 60 & $111.2 \mathrm{bc}$ & $22.7 \mathrm{bcd}$ & $11.6 \mathrm{ab}$ \\
\hline 6. Cloransulam-methyl & 40 & $121.5 \mathrm{abc}$ & $23.9 \mathrm{bcd}$ & $13.9 \mathrm{ab}$ \\
\hline 7. Glyphosate + metsulfuron-methyl & $960+2.4$ & $25.9 \mathrm{~d}$ & $7.4 \mathrm{e}$ & $4.2 \mathrm{c}$ \\
\hline 8. Glyphosate + chlorimuron-ethyl & $960+20$ & $109.3 \mathrm{bc}$ & $21.2 \mathrm{~cd}$ & $15.3 \mathrm{ab}$ \\
\hline 9. Glyphosate + nicosulfuron & $960+60$ & $99.5 \mathrm{c}$ & $19.5 \mathrm{~d}$ & $13.3 \mathrm{ab}$ \\
\hline 10. Glyphosate + cloransulam-methyl & $960+40$ & $113.9 \mathrm{bc}$ & $23.9 \mathrm{bcd}$ & $13.5 \mathrm{ab}$ \\
\hline Average & & 100.60 & 20.70 & 12.47 \\
\hline $\mathrm{VC}(\%)$ & & 9.01 & 8.82 & 22.66 \\
\hline
\end{tabular}

${ }^{1 /}$ Grams of active ingredient per hectare. Doses in grams of equivalent acid per hectare (g e.a. ha $\left.{ }^{-1}\right)$, glyphosate herbicide. $*$ Averages followed by the same letter in column do not differ statistically between each other at $5 \%$ probability by Tukey test. ${ }^{* *}$ FMAP (fresh mass aerial part); DMAP (dry mass aerial part); DMRS (dry mass root system). 
According to Menendez et al. (1994), there are differences in the resistance level in genotypes tolerant to herbicides from the sulfonylureas group. Also, susceptibility to chlorimuron-ethyl may vary according to the soybean genotype (Mian et al., 1997). Therefore, different STS cultivars may present different levels of tolerance to sulfonylureas. Viana et al. (2014) have verified that cultivar CD 250 RR/STS was tolerant to metsulfuronmethyl application while, in the present study, cultivar CD $2630 \mathrm{RR} / \mathrm{STS}$ was not tolerant to this herbicide's application.

It is important to highlight that sulphonylorea is not recommended for application in soybean crop. However, cultivar CD $2630 \mathrm{RR} / \mathrm{STS}$ was tolerant for application post-emergence of nicosulfuron (60 g a.i. ha-1), with more studies being necessary to a better positioning of its use in front of this technology in other STS cultivars.

In a broad sense, soybean cultivar CD 2630 RR/STS has shown itself as tolerant to application post-emergence (V4) to the used herbicides, with or without association to glyphosate, except for metsulfuron-methyl (2.4 $\mathrm{g}$ a.i. $\left.\mathrm{ha}^{-1}\right)$, which, with or without association to glyphosate (960 g a.e. ha-1), have caused irreversible damages to the crop.

\section{REFERENCES}

Albrecht L.P. et al. Glyphosate e associações em pósemergência no desempenho agronômico e na qualidade das sementes de soja $R^{\circledR}{ }^{\circledR}$. Planta Daninha. 2012;30:139-46.

Belfry K.D. et al. Tolerance of identity preserved soybean cultivars to preemergence herbicides. Can J Plant Sci. 2015;95:719-26.

Chahal P.S. et al. Efficacy of pre-emergence and postemergence soybean herbicides for control of glufosinate-, glyphosate-, and imidazolinone-resistant volunteer corn. J Agric Sci. 2014;6:131-40.

Céleres. Informativo Céleres - Projeção de safra - 2015/ 2016: soja, setembro de 2015. 2015a. [acesso em: 14 set. 2015]. Disponível em: http://celeres.com.br/ic15-09-projecaode-safra-soja-setembro-2015/.

Céleres. Informativo biotecnologia: safra 2014/2015, terceiro levantamento, julho de 2015. Uberlândia: 2015b. 7p.
Conab. Acompanhamento da safra brasileira: grãos: safra 2014/2015, décimo segundo levantamento, setembro de 2015. Brasília: 2015. 139p.

Coodetec. 2012 - Guia de produtos. 2012. [acesso em: 11 jul. 2015]. Disponível em: http://www.coodet ec.com.br/ downloads/Guia_de_produtos_Soja_-_Sul_e_Paraguai.pdf.

DuPont. Ligate STS. 2012. [acesso em: 13 jul. 2015]. Disponível em: http://www.dupont.com.ar/content /dam / assets/products-and-services/crop-protection/assets/ Brochure_Ligate.pdf.

Empresa Brasileira de Pesquisa Agropecuária - Embrapa. Tecnologias de produção de soja: região central do Brasil 2014. Londrina: Embrapa Soja. 2013. 266p. (Sistemas de produção, 16).

Fehr W.R. et al. Stage of development description for soybean, Glycine max (L.) Merrill. Crop Sci. 1971;11:92931.

Gazziero D.L.P. Misturas de agrotóxicos em tanque nas propriedades agrícolas do Brasil. Planta Daninha. 2015;33:83-92.

Ghio C. et al. Molecular characterization of Als1, an acetohydroxyacid synthase mutation conferring resistance to sulfonylurea herbicides in soybean. Theor Appl Genet. 2013;126:2957-68.

Giovanelli B.F. et al. Efeito da aplicação de doses de nicosulfuron sobre soja RR/STS. In: Anais do $29^{\circ}$. Congresso Brasileiro da Ciência das Plantas Daninhas. Gramado: 2014.

Greene E.A. et al. The effect of the primary structure of DNA on induction of mutations by alkylating agents. Russian J. Genet. 2001;37:704-10.

Infocampo. Nuevas estrategias de DuPont para acorralar al Rye Grass. 2015. [acesso em: 19 out. 2015]. Disponível em: http://infocampo.com.ar/nota/campo/70486/nuevasestrategias-de-dupont-para-acorralar-al-rye-grass.

Maciel C.D.G. et al. Seletividade de cultivares de soja RR submetidos a misturas em tanque de glyphosate + chlorimuron-ethyl associadas a óleo mineral e inseticidas. Planta Daninha. 2009;27:755-68.

Marchi S.R. et al. Associações entre glifosato e herbicidas pós-emergentes para o controle de trapoeraba em soja $R R \AA$. Rev Bras Herbic. 2013;12:23-30.

Markwell J. et al. Calibration of the Minolta SPAD-502 leaf chlorophyll meter. Photosy Res. 1995;46:467-72.

Menendez J. et al. Resistance to chlortoluron of a slender foxtail (Alopecurus myosuroides) biotype. Weed Sci. 1994;42:340-4. 
Mian M.A.R. et al. RFLP Analysis of Chlorimuron Ethyl Sensitivity in Soybean. J Hered. 1997;88:38-41.

Oliveira Neto A.M. et al. Sistemas de dessecação em áreas de trigo no inverno e atividade residual de herbicidas na soja. Rev Bras Herbic. 2013;12:14-22.

Pimentel-Gomes F., Garcia C.H. Estatística aplicada a experimentos agronômicos e florestais: exposição com exemplos e orientações para uso de aplicativos. Piracicaba: FEALQ, 2002. 309p.

Procópio S.O. et al. Utilização de chlorimuron-ethyl e imazethapyr na cultura da soja Roundup Ready. Planta Daninha. 2007;25:365-73.

Reddy KN., Whiting K. Weed control and economic comparisons of glyphosate-resistant, sulfonylurea-tolerant, and conventional soybean (Glycine max) systems. Weed

Technol. 2000;14:204-211.

Riar D.S. et al. Adoption of best management practices for herbicide-resistant weeds in Midsouthern United States cotton, rice, and soybean. Weed Technol. 2013;27:788-97.

Rogozin I.B. et al. The effect of the primary structure of DNA on induction of mutations by alkylating agents.

Russian J Genet. 2002;37:704-710.
Roso A.C., Vidal R.A. Culturas resistentes aos herbicidas inibidores da enzima ALS: Revisão de literatura. Rev Ecotox Meio Amb. 2011;21:13-24.

Sebastian S.A. et al. Semidominant soybean mutation for resistance to sulfonylurea herbicide. Crop Sci. 1989;29:14038.

Shaner D.L. The impact of glyphosate-tolerant crops on the use of other herbicides and on resistance management. Pest Manage Sci. 2000;56:320-6.

Sociedade Brasileira de Ciência de Planta Daninha - SBCPD. Procedimentos para instalação, avaliação e analise de experimentos com herbicidas. Londrina: 1995. 42p.

Viana H.R.M. et al. Efeito da aplicação de doses de metsulfuron-methyl sobre soja RR/STS. In: Anais $29^{\circ}$. Congresso Brasileiro da Ciência das Plantas Daninhas. Gramado: 2014.

Walter K.L. et al. Molecular and phenotypic characterization of Als1 and Als2 mutations conferring tolerance to acetolactate synthase herbicides in soybean. Pest Manage Sci. 2014;70:1831-9.

Walsh K.D. et al. Weed control in soybean with imazethapyr applied alone or in tank mix with saflufenacil/dimethenamid-P. Weed Sci. 2015;63:329-35. 